\title{
Calculation Features of Trapezoidal Combined Ribbed Slabs on Wooden Frame
}

\author{
Viktor I. Zhadanov*a, \\ Ivan S. Inzhutov ${ }^{b}$ and Dmitrij A. Ukrainchenko ${ }^{a}$ \\ ${ }^{a}$ Orenburg State University \\ Orenburg, Russian Federation \\ ${ }^{b}$ Siberian Federal University \\ Krasnoyarsk, Russian Federation
}

Received 18.11.2019, received in revised form 25.12.2019, accepted 21.01.2020

Abstract. The article describes the features of design and calculation of ribbed slabs on wooden frame with trapezoidal plan, where the cover is included in the general work of the structure on operational loads. The field of possible application of the investigated elements is shown. The features of trapezoidal slab design are described. The main provisions of the proposed method of the considered structures class calculation are reflected. The formula dependencies of trapezoidal slabs calculation on deformations have been determined due to the use of the calculation method of structures that consist of different module materials; the outcomes of previous numerical studies carried out by the authors of the paper as well as the algorithms of a numerical functions determination based on a particular integral method. The location of a weak slab section when calculating on a normal stress has been defined with the regard to a part of an operating cover, which varies along the span length. It is shown that the proposed method allows to assess adequately the stress-deformed state of trapezoidal slabs and to calculate them on strength and rigidity according to the suggested algorithm.

Keywords: trapezoidal ribbed slabs, combined structure, application area, rib, cover, diaphragm, calculation method, stress-deformed state, reduction factor, weak section, calculation algorithm, approximation.

Citation: Zhadanov V.I., Inzhutov I.S., Ukrainchenko D.A. Calculation features of trapezoidal combined ribbed slabs on wooden frame, J. Sib. Fed. Univ. Eng. \& Technol., 2020, 13(1), 100-110. DOI: 10.17516/1999-494X-0208

(C) Siberian Federal University. All rights reserved

This work is licensed under a Creative Commons Attribution-NonCommercial 4.0 International License (CC BY-NC 4.0).

* Corresponding author E-mail address: organ-2003@bk.ru 


\title{
Особенности расчета
}

\section{трапециевидных совмещенных ребристых плит}

на деревянном каркасе

\author{
В.И. Жаданов ${ }^{\mathrm{a}}$, И.С. Инжутов ${ }^{\sigma}$, Д.А. Украинченко \\ ${ }^{a}$ Оренбургский государственный университет \\ Российская Федерачия, Оренбург \\ ${ }^{6}$ Сибирский федеральный университет \\ Российская Федерация, Красноярск
}

\begin{abstract}
Аннотация. В статье рассмотрены особенности конструирования и расчета ребристых плит на деревянном каркасе с трапециевидным планом, у которых обшивка включена в общую работу конструкции на восприятие эксплуатационных нагрузок. Показана область возможного применения исследуемых элементов. Описаны особенности конструкции трапециевидных плит. Отражены основные положения предлагаемой методики расчета рассматриваемого класса конструкций. С применением метода расчета конструкций, состоящих из разномодульных материалов, результатов ранее проведенных авторами статьи численных исследований, а также алгоритмов численного определения функций на основе методики определенного интеграла, установлены формульные зависимости расчета трапециевидных плит по деформациям. Местоположение опасного сечения плиты при расчете по нормальным напряжениям вычислено с учетом доли работающей обшивки, которая изменяется по длине пролета. Показано, что предложенная методика позволяет адекватно оценивать напряженнодеформированное состояние трапециевидных плит и производить их расчет на прочность и жесткость по предложенному алгоритму.
\end{abstract}

Ключевые слова: трапециевидные ребристые плиты, совмещенная конструкция, область применения, ребро, обшивка, диафрагма, методика расчета, напряженно-деформированное состояние, коэффициент приведения, опасное сечение, алгоритм расчета, аппроксимация.

Цитирование: Жаданов, В.И. Особенности расчета трапециевидных совмещенных ребристых плит на деревянном каркасе / В.И. Жаданов, И.С. Инжутов, Д.А. Украинченко // Журн. Сиб. федер. ун-та. Техника и технологии, 2020. 13(1). С. 100-110. DOI: 10.17516/1999-494X-0208

\section{Introduction}

The construction volume growth with the use of wood and the development of the glued wooden structures base have resulted in a wide application of ribbed slabs on the wooden frame with the largest overall dimensions that are possible according to technological parameters and transportability conditions in buildings of various purposes. Such structures allow to increase the degree of factory elements readiness that are supplied to the construction site; to reduce the objects construction time and, at the same time, to improve the quality of installation and construction works. The highest degree of efficiency is provided by slabs, where the combination principle of bearing and enclosing functions is realized. This principle suggests that the main longitudinal ribs act as beams and covers together with auxiliary elements are fences of buildings [1-3]. In the slabs on the wooden frame, such combination is achieved by gluing the cover to the ribs, and due to that they are included into the overall operation of the structure. It significantly increases the geometric characteristics of the cross sections. 
The stress-strain state features of the combined slabs on the wooden frame with a rectangular plan as well as the method of their calculation have been studied by Russian and foreign researchers. In Russia the studies were carried out by V.N. Bykowsky, A.B. Gubenko, P.A. Dmitriev, V.A. Ivanov, Y.M. Ivanov, L.M. Kowalchuk, S.V. Kolpakov, S.G. Lyakhnitsky, I.M. Linkov, D.V. Martinez, R.B. Orlovich, G.G. Rostovtsev, E.I. Svetozarova, E.N. Serov, B.S. Sokolovsky, Y.D. Strizhakov. Modern Russian normative documents on rectangular slabs calculation on wooden frame with the regard to joint work of ribs and plywood covers are based on the results of experimental and theoretical studies of A.B. Gubenko [4]. The calculation is carried out according to the method of transformed section. In this case, wood is brought to the cover material by means of the coefficient $n=E_{\partial} / E_{o}$, which considers different modularity of materials in the calculated sections. In addition, the cover area in the calculation is introduced in terms of the reduction factor $k_{\sigma \sigma}$, which considers the cover inclusion degree in the general operation of the structure [5-7].

In this respect, regarding the high architectural and aesthetic qualities of raised objects, the cover configurations in plan often differ from rectangular. It is predetermined by the use of trapezoidal elements. A perfect example of it is a building with polygonal, circular, ellipse plans in dome structures, etc. When using trapezoidal slabs in roof or floors in buildings, a designer deals with the problem that the width of their cross-section and the magnitude of the real load change linearly along the whole length of the span, and the height of the main ribs can also change, for example, in order to create the necessary roof slope. When changing the width of the cross section, the degree of cover involvement in the overall operation of the slab also changes. Such degree generally depends on the space between ribs, and it varies linearly, as well as the width along the length of the span. However, these features are considered neither in available methods or normative and technical sources. There are no clear methods for calculating combined rib slabs on a wooden frame with a trapezoidal plan. In this regard, the development of such methods is an urgent task, which will increase the competitiveness of wooden panel structures and contribute to the expansion of their implementation in construction practice.

\section{Research Object}

The object of the research is a trapezoidal ribbed slab on a wooden frame with a cover that is glued to the main ribs and involved in the overall operation of the structure.

\section{Research Objective}

The objective of the research is to investigate theoretically the features of the stress-deformed state of trapezoidal combined rib slabs on the wooden frame with the calculation suggestions.

\section{Research Methodology}

When studying and experimenting, some tested and widely used methods of calculation of structures that consist of different module materials; outcomes of previous numerical studies; algorithms of numerical functions determination based on the methodology of a particular integral were used. 


\section{Results of Research}

The features of the plan regarding the structural technological requirements determine a few issues that are necessary to be considered when developing the trapezoidal slabs. The issues are as follows:

- minimum width of the slab should be no less than $500 \mathrm{~mm}$ (the condition of structural connections with underlying constructions);

- maximum width of the slab is limited to $3000 \mathrm{~mm}$ (transportation condition);

- the cross section is generally U-shaped (condition of minimum distance between major ribs);

- orientation of auxiliary ribs is taken across the slab span (conditions for stability of compressed cover and manufacturing).

The example of design solution of trapezoidal slab and its parameters are given in Fig. 1.

In addition, when determining the overall dimensions of slabs with trapezoidal plan, it is necessary to consider the specified design data of the building or structure.

For example, let us consider a circular building in plan, where $R, r$ - the dimensions of the outer and inner support contours, $l_{n}$ - the slab span (Fig. 2). The tolerances for values $b_{0}, b_{l}, l_{n}$ are given:

$$
\begin{aligned}
& b_{0 \text { min }} \leq b_{0} \leq b_{0 \text { max }} \\
& b_{1 \text { min }} \leq b_{1} \leq b_{1 \text { max }} \\
& l_{0}=6,0 \ldots 18,0 \mathrm{~m} \text {. }
\end{aligned}
$$
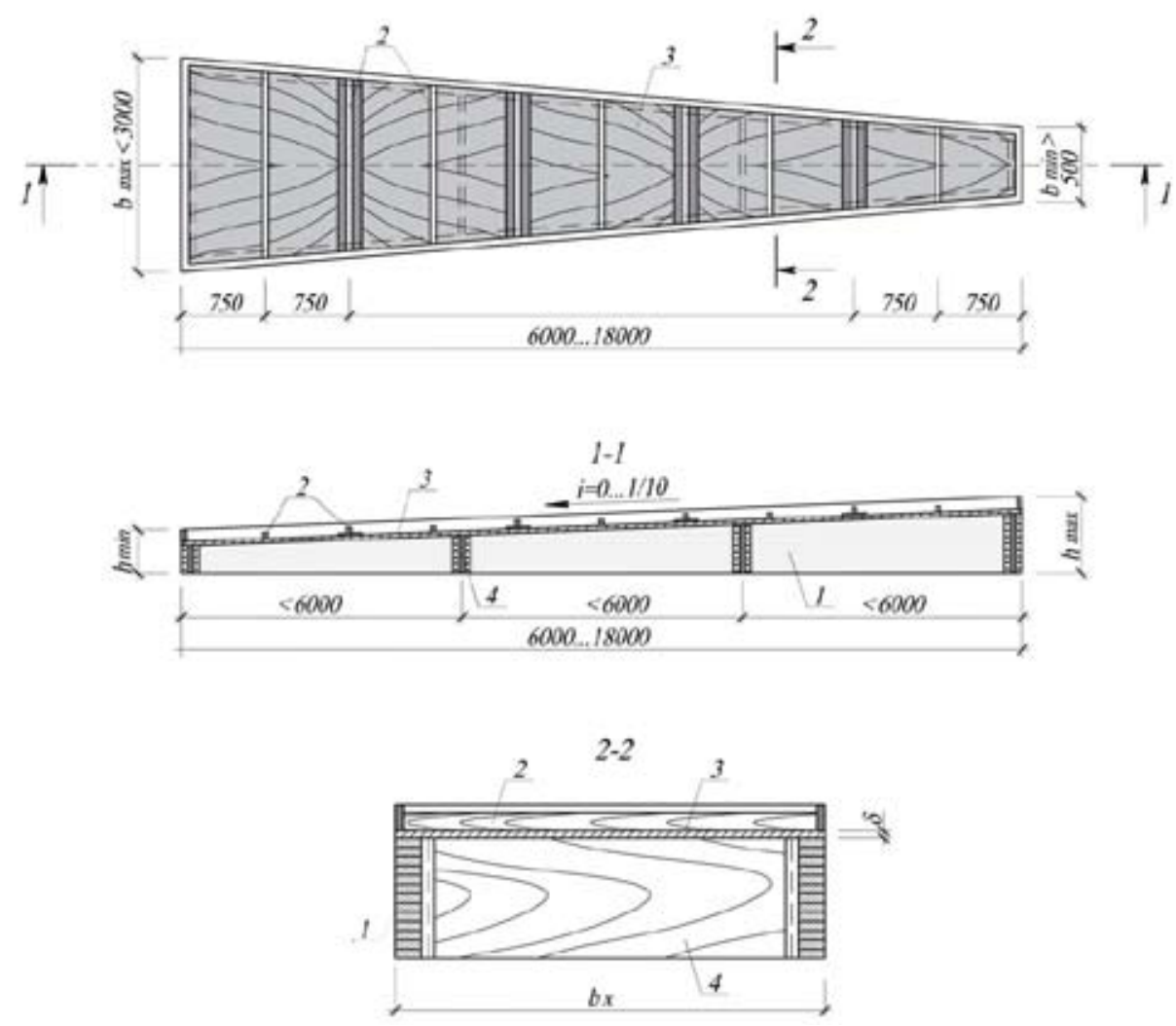

Fig. 1. The main parameters of trapezoidal slabs: 1 - main ribs; 2 - auxiliary ribs; 3 - cover; 4 - diaphragms 
a)
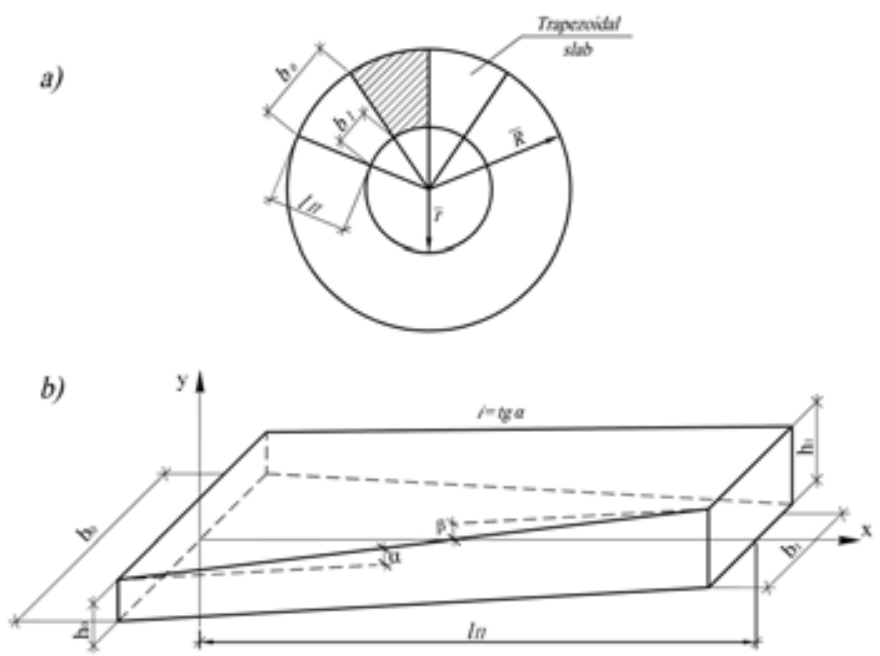

c)

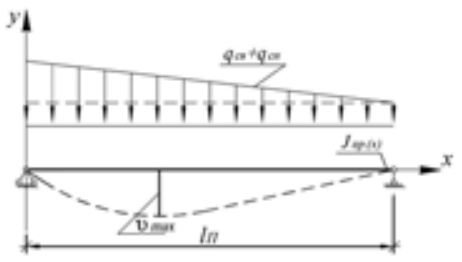

Fig. 2. The trapezoidal slabs calculation: $a-$ designation of building parameters with a circular plan; $b$ - designation of slab parameters; $\mathrm{c}$ - design diagram

As a rule, the values $b_{0}$, and $b_{1}$ are in the range of $1,5 \leq b_{0} \leq 3,0 m ; 0,5 \leq b_{1} \leq 1,0 \mathrm{~m}$ for trapezoidal slabs.

The outer radius $R$ is the main initial parameter.

Then, the number of overlapping slabs " $n$ " will be in the range:

$$
n_{\min } \leq n \leq n_{\max },
$$

where $\quad n_{\min }=\frac{2 \pi R}{b_{0 \max }}-$ rounded to an integer up; $n_{\max }=\frac{2 \pi R}{b_{0 \min }}-$ rounded to an integer down.

Accordingly, the required radius " $r$ " of the inner support contour with the selected number of slabs is in the range:

$$
\frac{n \cdot b_{1 \min }}{2 \pi} \leq r \leq \frac{n \cdot b_{1 \max }}{2 \pi}
$$

The total tolerance interval for " $\mathrm{r}$ " is:

$$
\frac{n_{\min } \cdot b_{1 \min }}{2 \pi} \leq r \leq \frac{n_{\max } \cdot b_{1 \max }}{2 \pi} .
$$

When the radius of the inner support contour is set, it must be checked for validity according to (4). 
The choice of the slabs size in the plan depends to a large extent on the conditions. When it is necessary to maximize the part of the plan area covered by the slabs (for example, for tower structures), the following should be accepted:

$$
\begin{aligned}
& r=r_{\text {min }}=\frac{n_{\text {min }} \cdot b_{1 \min }}{2 \pi}, \\
& l_{n}=l_{\text {max }}=R-r_{\text {min }} .
\end{aligned}
$$

For example, let the outer radius of the tower-type structure be $R=18,0 \mathrm{~m}$. Then, according to the above suggestions:

$$
\begin{aligned}
& n_{\text {min }}=\frac{2 \cdot 3,14 \cdot 18}{3}=37,68 \Rightarrow n_{\text {min }}=38, \\
& r_{\text {min }}=\frac{38 \cdot 0,5}{2 \cdot 3,14}=3,025 \mathrm{M},
\end{aligned}
$$

i.e., in the structure either an additional row of columns located along the inner radius or a central column with $3.025 \mathrm{~m}$ cantilevers is required to provide the inner support contour.

According to the design diagram (Fig. 2c), the location of weak section and calculation of slabs on deformations are the features of trapezoidal slabs calculation. The following methodology is proposed to consider such features.

When determining the location of the weak section in trapezoidal plan slabs, it is necessary to note that the step of major ribs is linearly variable along the length of the slabs. In this case, the reduction factor of plywood cover depends on the coordinate of the section $x$ and can be determined according to the formula:

$$
k_{o \sigma}(x)=k_{2}(x) \cdot \delta_{\phi}^{2}+k_{l}(x) \cdot \delta_{\phi}+k_{0}(x),
$$

where, $k_{2}(x), k_{1}(x), k_{0}(x)$ - functions that can be found from quadratic approximation:

$$
\begin{aligned}
& k_{2}(x)=k_{2}\left(b_{n}(x)\right)=a_{22} \cdot b_{n}^{2}(x)+a_{21} \cdot b_{n}(x)+a_{20}, \\
& k_{1}(x)=k_{l}\left(b_{n}(x)\right)=a_{12} \cdot b_{n}^{2}(x)+a_{11} \cdot b_{n}(x)+a_{10}, \\
& k_{0}(x)=k_{0}\left(b_{n}(x)\right)=a_{02} \cdot b_{n}^{2}(x)+a_{01} \cdot b_{n}(x)+a_{00},
\end{aligned}
$$

$\delta_{\phi}-$ plywood cover thickness, $\mathrm{cm}$.

The dependencies for the coefficients of quadratic approximations in formulas (8) are easily found in terms of the quadratic approximations that are given [8] with respect to rectangular plan ribbed slabs. For example, the values of the coefficients of the quadratic approximation $k_{2}\left(b_{n}(x)\right)$ can be found by solving a system of linear equations:

$$
\left\{\begin{array}{l}
a_{22} \cdot 0,75^{2}+a_{21} \cdot 0,75+a_{20}=-0,042 \\
a_{22} \cdot 1,5^{2}+a_{21} \cdot 1,5+a_{20}=-0,029 \\
a_{22} \cdot 3,0^{2}+a_{21} \cdot 3,0+a_{20}=-0,014
\end{array} .\right.
$$

The approximation coefficients for $k_{l}\left(b_{n}(x)\right)$ and $k_{0}\left(b_{n}(x)\right)$ can similarly be defined.

$$
-105-
$$


The function $b_{n}(x)$ is linear, that is, it can be defined according to the symbols of Fig. 2 from the expression:

$$
b_{n}(x)=b_{0}+\frac{b_{1}-b_{0}}{l_{n}} x
$$

If we substitute (10) for (8), the final dependencies for the approximation coefficients (7) are obtained.

Then, the algorithm of the weak section location, like the slabs of constant width, is as follows.

1. Define the design width of plywood cover:

$$
b_{\phi}(x)=k_{o \sigma}(x) \cdot\left(b_{n}(x)-b \cdot m_{o p}\right)+b \cdot m_{o p} .
$$

2. Calculate the area of the transformed section of the slab:

$$
A_{n p}=A_{\delta}+n \cdot A_{\phi}(x)=m_{n p} b\left(h_{o n}+i \cdot x\right)+n \cdot \delta_{\phi}(x) .
$$

3. Calculate the reduced static moment of arbitrary section:

$$
S_{n p}(x)=\frac{1}{2} m_{o p} \cdot b \cdot\left(h_{o n}+i \cdot x\right)^{2}+n \cdot A_{\phi}(x) \cdot\left(h_{o n}+i \cdot x+\frac{\delta_{\phi}}{2}\right)
$$

4. Determine the position of neutral axis of arbitrary section:

$$
y_{0}(x)=\frac{S_{n p}(x)}{A_{n p}(x)} .
$$

5. Find the moment of inertia of an arbitrary cross section:

$$
\begin{aligned}
& J_{n p}(x)=m_{o p} \cdot b \cdot\left(h_{o n}+i \cdot x\right)\left[\frac{\left(h_{o n}+i \cdot x\right)^{2}}{12}+\left(y_{0}(x)-\frac{\left(h_{o n}+i \cdot x\right)^{2}}{12}\right)\right]+ \\
& +n \cdot \delta_{\phi} \cdot b_{\phi}(x) \cdot\left(h_{o n}+i \cdot x-y_{0}+\frac{\delta_{\phi}}{2}\right)^{2} .
\end{aligned}
$$

Make the expression (or algorithm) for determining normal stresses at the points of slab arbitrary section:

$$
\sigma(x, y)=\frac{M(x) \cdot\left(y_{0}(x)-y\right)}{I_{n p}(x)}
$$

where $M(x)$ - bending moment in arbitrary section of slab $0 \leq x \leq l_{n}$

Define the maximum:

$$
\begin{aligned}
& \max _{x, y}\left|\frac{M(x) \cdot\left(y_{0}(x)-y\right)}{J_{n p}(x)}\right| . \\
& 0<x \leq l_{n,} 0 \leq y \leq\left(h_{o n}+i \cdot x\right)+\delta_{\phi} .
\end{aligned}
$$

When only normal stresses are considered while determining the weak section which is quite true for combined slabs where the ratio of the maximum height of the main ribs cross section to the span is small and is about $1 / 15 \ldots 1 / 24$, it is possible to check only the extreme (bottom and top) points of the section by normal stresses, that is 


$$
y=\mid \begin{aligned}
& 0 \\
& h_{o n}+i \cdot x+\delta_{\phi}
\end{aligned} .
$$

The determination of $\max \sigma_{\text {эк }}(x, y)$ can be calculated by any strength theory. The normal, tangent and main stresses must be determined at the points of the cross section.

The maximum values of the main stresses $\max _{x, y}\left|\sigma_{э к в}(x, y)\right|$ or $\max _{x, y} \sigma_{э к в}(x, y)$ can be determined by means of a search algorithm of an absolutely extreme problem solution, including by scanning over a selected grid $x, y$.

To determine trapezoidal slab deformations, it is advisable to use differential equation of beams bending:

$$
\mathrm{v}^{\prime \prime}(x)=\frac{M(x)}{E \cdot J_{n p}(x)} .
$$

Using the methodology of a particular integral, let us build an epure $v$.

The numerical determination algorithm of $v(\mathrm{x})$ based on the methodology of a particular integral is:

1. Choose a step of numerical integration $\Delta$ and build the epure $\frac{M(x)}{E \cdot J_{n p}(x)}$. It approximately coincides with the epure $v^{\prime \prime}(x)$ (Fig. 3, a) where $n$ is the number of splitting sites of a slab, $0 \leq x \leq n \cdot \Delta$, $x_{j}=\Delta \cdot j$.

For design scheme with hinged support $M(0)=M(l)=0$.

$$
\ni n \frac{M(x)}{E \cdot J_{n p}(x)} \approx Э n v^{\prime \prime}(x) .
$$

a) $y$

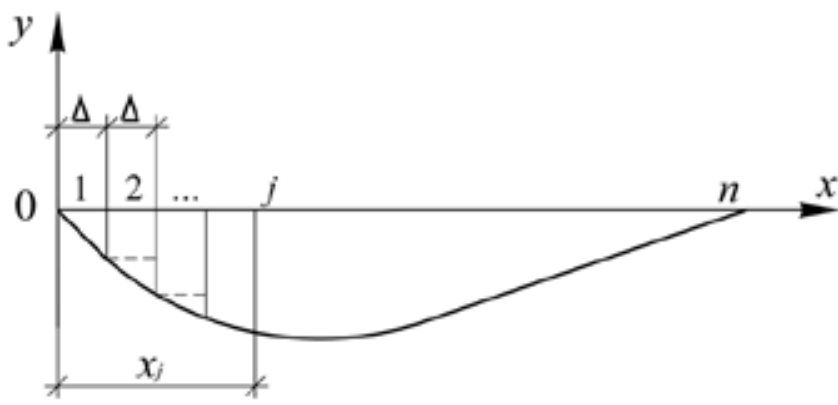

b)

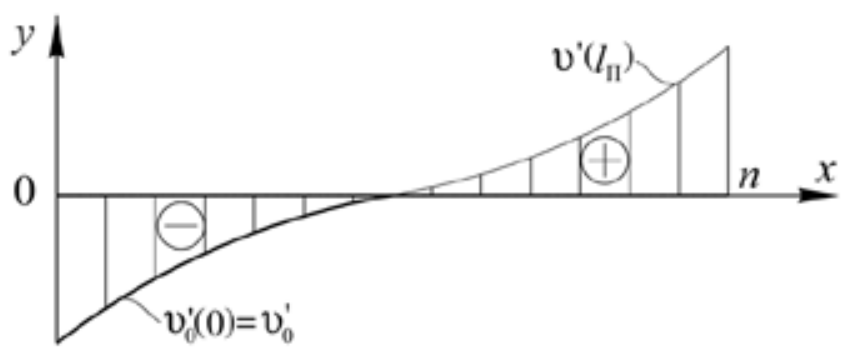

Fig. 3. Nature of epure $\frac{M_{x}}{E \cdot J_{n p}(x)} \approx \ni n v^{\prime \prime}(x)$ at distributed load of intensity $q(x)$ (a) and epure $v^{\prime}(x)$ (b) 
2. Build epure $v^{\prime}(x)$ by using dependence (18) and performing step-by-step numerical integration (Fig. 3b).

3. Obtain the expression for the first derivatives by averaging the values of the second derivative in the split step:

$$
v^{\prime}\left(x_{j}\right)=v_{0}^{\prime}+\left(\frac{v^{\prime \prime}(0)+v^{\prime \prime}\left(x_{j}\right)}{2}+\sum_{k=1}^{j-1} v^{\prime \prime}\left(x_{k}\right)\right) \cdot \Delta,
$$

where $j=1, \ldots n ; v_{0}^{\prime}-$ initial angle of rotation; $\Delta$ - splitting step;

$$
v^{\prime \prime}\left(x_{j}\right)=\frac{M\left(x_{j}\right)}{E \cdot I_{n p}\left(x_{j}\right)} .
$$

Introduce the following symbols. Let it be as follows:

$$
\Delta V_{j}^{\prime}=\left(\frac{v^{\prime \prime}(0)+v^{\prime \prime}\left(x_{j}\right)}{2}+\sum_{k=1}^{j-1} v^{\prime \prime}\left(x_{k}\right)\right) \cdot \Delta,
$$

where $j=1, \ldots, n$.

Then formula (20) will be as follows:

$$
v^{\prime}\left(x_{j}\right)=v_{0}^{\prime}+\Delta V_{j}^{\prime}
$$

where $j=1, \ldots, n$.

4. Similarly to (20), calculate values $v\left(x_{j}\right)$.

As $v\left(x_{0}\right)=v(0)=v_{0}=0$, then:

$$
v\left(x_{j}\right)=\left(\frac{v_{0}^{\prime}+v^{\prime}\left(x_{j}\right)}{2}+\sum_{k=1}^{j-1} v^{\prime}\left(x_{k}\right)\right) \cdot \Delta .
$$

Using the dependency (23), obtain:

$$
v\left(x_{j}\right)=\left(v_{0}^{\prime} \cdot j+\frac{\Delta V_{j}^{\prime}}{2}+\sum_{k=1}^{j-1} \Delta V_{k}^{\prime}\right) \cdot \Delta .
$$

If $x_{j}=l_{n}$ :

$$
v\left(x_{n}\right)=v\left(l_{n}\right)=\left(v_{0}^{\prime} \cdot n+\frac{\Delta V_{n}^{\prime}}{2}+\sum_{k=1}^{n-1} \Delta V_{k}^{\prime}\right) \cdot \Delta=0
$$

Therefore:

$$
v_{0}^{\prime}=-\frac{\left(\frac{\Delta V_{n}^{\prime}}{2}+\sum_{k=1}^{n-1} \Delta V_{k}\right)}{n} .
$$

Using dependencies (24 - 27), build узгку v, and

$$
\max |v|=\max \left|v\left(x_{j}\right)\right|,
$$

where $j=1, \ldots, n-1$. 
Apart from this, the algorithm of trapezoidal slabs calculation is completely like the algorithm of combined slabs calculation on a wooden frame with a rectangular plan.

\section{Conclusion}

The proposed method of combined slabs calculation on a wooden frame with a trapezoidal plan allows to assess their stressed-deformed state adequately, to carry out practical calculations for strength and rigidity. It makes possible to use full-board trapezoidal elements in construction practice for roofs and floors of buildings and structures of different purposes successfully.

\section{References}

[1] Ковальчук Л.М. Деревянные конструкции - проблемы и решения. Промышленное $и$ гражданское строительство, 2001, 10, 13-14 [Kovalchuk L.M. Wooden structures - problems and solutions. Industrial and civil engineering, 2001, 10, 13-14 (in Russian)]

[2] Пятикрестовский К.П. Вопросы дальнейшего совершенствования конструкций с применением древесины и новых плитных материалов. Пространственные конструкции, сб. трудов РААСН, 2007, 9, 49-51 [Pyatikrestovsky K.P. Issues of further improvement of structures with the use of wood and new tile materials. Spatial Constructions, In the collection of works of RAASN, 2007, 9, 49-51 (in Russian)]

[3] Гетц К.Г., Хоор Д., Мелер К., Наттерер Ю. Атлас деревянных конструкиий. Пер. с нем. М.: Стройиздат, 1985, 272 c. [Getz K.G., Hoor D., Meler K., Natterer Y. Atlas of wooden structures. Translation from German. Moscow, Stroyizdat, 1985, 272 p. (in Russian)]

[4] Губенко А.Б. Клееные деревянные конструкции в строительстве. М.: Госстройиздат, 1957. 240 c. [Lubenko A.B. Glued wooden structures in construction. Moscow, Gosstroizdat, 1957, 240 p. (in Russian)]

[5] Торяник Н.Н., Корзон С.А. Расчет клеефанерных плит покрытия. Конструкции из клееной древесины и пластмасс. Межвузовский тематический сборник трудов ЛИСИ. 1978, 2, 58-64 [Toryanik N.N., Korzon S.A. Calculation of glued plywood roof slabs. Structures of glued wood and plastics, Inter-university thematic collection of LISI works, 1978, 2, 58-64 (in Russian)]

[6] Орлович Р.Б., Григорьева Л.И.Напряженно-деформированноесостояние клеефанерных плит при длительном загружении. Известия ВУЗов. Строительство и архитектура, 1988, 10, 105-107 [Orlovich R.B., Gregory L.I. Stress-deformed state of glued plywood slabs at longitudal load, News of universities. Construction and architecture, 1988, 10, 105-107 (in Russian)]

[7] Инжутов И.С., Жаданов В.И., Никитин В.М. Исследование напряженнодеформированного состояния крупноразмерной ребристой плиты с обшивкой, приклеенной на части длины конструкции. Известия ВУЗов. Строительство, 2008, 7, 4-10 [Inzhutov I.S., Zhadanov V.I., Nikitin V.M. Reseach of stress-deformed state of large-size ribbed slab with cover glued on part of the length of the structure. News of higher education institutions. Construction, 2008, 7, 4-10 (in Russian)]

[8] Гребенюк, Г.И., Яньков Е.В., Ажермачев А.В. Оптимизация параметров большеразмерных ребристых плит на основе древесины. Проблемы оптимального проектирования сооружений: сборник докладов V Всероссийского семинара. Новосибирск: НГАСУ (Сибстрин), 2005, 110-119 
[Grebenyuk G.I., Yankov E.V., Ajermachev A.V. Optimization of parameters of large-scale ribbed slabs on the basis of wood, Problems of optimal design of structures: collection of reports of the V All-Russian seminar. Novosibirsk, NGASU (Sibstrin), 2005, 110-119 (in Russian)] 